\title{
UPAYA PENINGKATAN MOTIVASI BELAJAR MATEMATIKA DENGAN MENGGUNAKAN ALAT PERAGA DI KELAS III SD ISLAM DATOK SULAIMAN PALOPO
}

\author{
Alni \\ Institut Agama Islam Negeri Palopo \\ Jl. Agatis Balandai Kota Palopo, Sulawesi Selatan, Indonesia \\ E-mail: alnhymarsani010@gmail.com
}

\begin{abstract}
This study aims to find out that there is an increase in the use of teaching aids so that they are motivated to study in Grade III Islamic Elementary School Datok Sulaiman Palopo, To find out student learning motivation can be improved by using teaching aids in class III Islamic Elementary School Datok Sulaiman Palopo. (PTK) which consists ofB two cycles each cycle carried out 3 meetings with the stages of planning, implementation, observation and reflection. The subjects of this study were Grade III Islamic SD Datok Sulaiman Palopo students in the odd semester of the 2018/2019 academic year with 28 students. Sources of data used in this study are primary data and secondary data, data collection techniques in this study are interviews, observation, questionnaires and documentation. data obtained shows that the average value in class III before the use of props in prasiklus 53.39. In the first cycle researchers have used teaching aids and the results of the average student scores are 80.53, but in this learning there are still a number of students who have not been maximal and researchers plan to make improvements and continue to cycle II. Then the average student score reaches 89.82. Based on completeness criteria (KKM) in mathematics subjects have achieved results and researchers ended this study until the second cycle.
\end{abstract}

Keywords:,Motivation to learn, teaching aids

\begin{abstract}
Abstrak
Penelitian ini bertujuan untuk mengetahui adanya peningkatan penggunaan alat peraga sehingga termotivasi untuk belajar di kelas III SD Islam Datok Sulaiman Palopo, Untuk mengetahui motivasi belajar siswa dapat ditingkatkan dengan penggunaan alat pe raga di kelas III SD Islam Datok Sulaiman Palopo. Penelitian ini menggunakan penelitian tindakan kelas (PTK) yang terdiri dari dua siklus masing-masing siklus dilaksanakan 3 kali pertemuan dengan tahapan perencanaan, pelaksanaan, observasi dan refleksi. Subjek penelitian ini adalah siswa kelas III SD Islam Datok Sulaiman Palopo pada semester ganjil tahun pelajaran 2018/2019 dengan jumlah siswa 28 orang. Sumber data yang digunakan adalah data primer dan data sekunder, tekhnik pengumpulan data dalam penelitian ini adalah wawancara, observasi, angket dan dokumentasi. Data yang diperoleh menunjukkan bahwa nilai rata-rata di kelas III sebelum penggunaan alat peraga pada prasiklus 53,39. Pada siklus I peneliti telah menggunakan alat peraga dan hasil nilai siswa rata-rata 80,53, namun dalam pembelajaran ini masih ada beberapa siswayang belum maksimal dan peneiti merencanakan untuk melakukan perbaikan dan dan dilanjutkan ke siklus II. Maka hasil nilai siswa rata-rata mencapai 89,82. Berdasarkan kriteria ketuntasan (KKM) pada mata pelajaran matematika sudah mencapai hasil dan peneliti mengakhiri penelitian sampai siklus II.
\end{abstract}

Kata Kunci,: Motivasi Belajar, Alat Peraga 


\section{PENDAHULUAN}

Pendidikan dipandang sebagai usaha sadar dan terencana untuk meningkatkan kualitas pendidikan yang menjadi pondasi utama suatu insan. Satu perubahan yang terjadi akan menyebabkan perubahan berikutnya dan akan berguna bagi proses belajar berikutnya (Slameto, 2013:3). Pendidikan bermaksud membantu peserta didik untuk menumbuh kembangkan potensipotensi kemanusiaannya. Benih kemanusiaan merupakan benih untuk menjadikan manusia yang lebih baik. Adanya perkembangan di dunia pendidkan turut serta dalam mempererat hubungan antar bangsa dalam berbagai sektor kehidupan (Rustan, 2001). Menurut Degeng dan Miarso dalam buku Belajar dan Pembelajaran mengungkapkan bahwa pembelajaran adalah suatu proses yang dilakukan secara sistematik karena setiap komponen saling berpengaruh. Dalam proses secara implisit terdapat kegiatan memilih, menetapkan dan mengembangkan metode untuk mencapai hasil pembelajaran yang lebih baik (Abdul Haling, 2007: 14)

Menurut (Undang-undang dan Peraturan RI tentang Pendidikan:4) Tujuan pendidikan di Indonesia sesuai dengan yang tercantum dalam UndangUndang No 20 Tahun 2003 pasal 1 tentang sistem Pendidikan Nasional merupakan usaha sadar dan terencana guna mewujudkan suasana belajar dalam proses pembelajaran agar peserta didik secara aktif mengembangkan potensi dirinya untuk memilih kekuatan spritual keagamaan, pengendalian diri, kepribadian, kecerdasan, akhlak mulia, serta keterampilan yang diperlukan dirinya, masyarakat, bangsa dan negara. Belajar merupakan tindakan dan perilaku peserta didik yang kompleks. Matematika pada dasarnya mengajarkan logika berpikir berdasarkan akal dan nalar (Dimyati dan Mudjiono,2009:7).

Pembelajaran merupakan situasi yang sengaja dibuat oleh guru guna membelajarkan siswa, pembelajaran berusaha mengubah masukan siswa yang tidak baik, menjadi siswa yang baik, siswa yang belum memiliki pengetahuan menjadi siswa yang memiliki pengetahuan. Demikian pula siswa yang memiliki sikap, kebiasaan atau tingkahlaku yang belum mencerminkan eksistensi dirinya sebagai pribadi baik atau positif, menjadi siswa yang mempunyai sikap, kebiasaan dan tingkah laku yang baik (Aunurrahman, 2014:34).

Matematika merupakan komponen mata pelajaran yang mempunyai peranan penting dalam pendidikan. Dari penjelasan tersebut maka diartikan pembelajaran Matematika merupakan salah proses belajar mengajar yang dibangun oleh guru untuk mengembangkan kreativitas berfikir siswa yang dapat meningkatkan kemampuan berfikir siswa, serta dapat meningkatkan kemampuan mengkonstruksi pengetahuan baru sebagai upauya 
meningkatkan penguasa yang baik terhadap materi matematika (Fatrima Santri Syafri, 2016:9).

Namun sampai saat ini masih ada sebagian siswa yang merasa matematika merupakan mata pelajaran yan paling sulit, tidak menyenangkan bahkan sangat menakutkan. Hal tersebut dikarenakan sebagian besar siswa yang masih mengalami kesulitan dalam menyelesaikan soal-soal matematika. Meskipun matematika masih dianggap memiliki tingkat kesulitan yang tinggi, akan tetapi setiap orang diharuskan mempelajarinya karena merupakan sarana untuk memecahkan suatu masalah. Matematika yang bersifat abstrak tersebut merupakan kesulitan tersendiri yang harus dihadapi peserta didik dalam mempelajari matematika (J.Tombokkan Runtukahu,2014:22) faktor faktor kesulitan belajar: 1.faktor kondisi fisik,2. Faktor lingkungan, 3. Faktor motivasi dan sikap, 4. Faktor psikologis (Rostina Sundayan,20015:3). Untuk menghasilkan proses pembelajaran yang baik dan berkualitas, guru seringkali mendapatkan masalah dalam memberikan materi pembelajaran. Khususnya kepada guru matematika dalam proses pembelajaran di sekolah masih mengalami kekurangan dan keterbatasan. Terutama dalam memberikan gambaran konkret dari materi yang disampaikan, sehingga hal tersebut berakibat langsung rendah. Pembelajaran yang menggunakan media yang cocok, akan mendapatkan hasil yang tepat, akan memberikan hasil yang optimal bagi pemahaman siswa terhadap materi yang dipelajarinya. Apabila kata media pendidikan digunakan secara bergantian dengan istilah alat bantu atau media komunikasi bahwa hubungan komunikasi akan berjalan lancar dan mendapatkan hasil yang maksimal jika menggunakan alat bantu atau yang disebut media

Masalah guru menurut (Syamsu S,2017:2) seringkali menjadi topik yang dibahas dalam berbagai pertemuan untuk mendapatkan alternatif pemecahan terhadap persoalan yang dihadapi guru dalam menjalankan tugasnya karena di ketahui bahwa pendidikan merupakan hal yang sangat penting bagi setiap manusia Pendidikan berfungsi membantu peserta didik dalam pengembangan dirinya, yaitu pengembangan semua potensi, kecakapan, serta karakteristik pribadinya ke arah yang positif, baik bagi dirinya maupun lingkungannya (Nana Syaodih Sukmadinata, 2009:4). Jika media tersebut berupa media pembelajaran, sasaran didik (audience) dapat diorganisasikan dengan baik, setelah mereka dapat menggunakan media tersebut secara teratur, berkesinambungan dan mengikuti tujuh tahap belajar mengajar tertentu. Agar penggunaan media dapat berjalan dengan efektif, maka perlu membuat persiapan yang efektif pula. Peralatan yang yang di gunakan untuk menggunakan media itu juga perlu di persiapkan terlebih dahulu (Abu ahmadi DKK, 2001:11). 
Dalam kaitannya dengan belajar mengajar, pemakaian istilah strategi di maksudkan sebagai daya upaya guru dalam menciptakan suatu sistem lingkungan yang memungkinkan terjadinya proses belajar mengajar. Maksudnya tujuan pengajaran yang telah di rumuskan agar tercapai dan berhasil, guru dituntut agar memiliki kemampuan mengatur secara komponen-komponen pengajaran sedemikian rupa sehingga saling berterkaitan fungsi dan komponen pengajaran dimaksud. Sehubu ngan dengan pembelajaran matematika maka guru disini sangat berperan penting dalam meningkatkannya pembelajaran tersebut, meningkat atau berkurangnya mutu pendidikan itu tergantung dari guru, sehubungan dengan itu guru merupakan tokoh utama dalam proses pembelajran agar siswa tidak mudah merasa jenuh atau bosan dalam pembelajaran masalah utama ialah kurangnya motivasi siswa dalam belajar. Motivasi belajar merupakan dorongan untuk mencapai keinginannya dan memenuhi kebutuhan yang datang dari dalam dirinya maupun yang datang dari luar dirinya. Motivasi belajar juga merupakan faktor emosi yang menyimpang (Sardiman,2011:75).

Peran motivasi dalam dalam penguatan belajar menurut (Hamzah B.Uno, 2012:27) apabila seorang anak yang belajar dihadapkan pada suatu masalahmasalah yang mengharapkan pemecahan, dan hanya dapat diselesaikan berkat bantuan hal-hal yang pernah dilaluinya sebagian contoh seorang anak yang akan memecahkan materi. Penguat belajar kepada seseorang apabila dia benar-benar memiliki motivasi untuk belajar sesuatu.

Peran motivasi juga dapat memperjelas tujuan belajar yang erat kaitannya dengan makna belajar. Tanpa motivasi belajar seorang peserta didik tidak akan belajar dan akhirnya tidak akan mencapai keberhasilan dalam belajar, yakni sebagai berikut: a. Motivasi Intrinsik merupakan motivasi yang berasal dari dalam diri seseorang. Dalam proses belajar mengajar siswa menjadi termotivasi secara intrinsik dapat dilihat dari ketekunan dalam mengerjakan tugas-tugas karena merasa butuh dan ingin mencapai tujuan belajar yang sebenarnya. b. Motivasi Ekstrinsik merupakan motivasi yang berasal dari luar atau dorongan orang lain. Motivasi sebagai kekuatan mental individu memiliki tingkat-tingkat (Made Wena,2013:33). Para ahli psikolog berpendapat berbeda mengenai tingkat kekuatan tersebut. Motivasi primer merupakan motivasi berdasarkan pada motif-motif dasar. Motif-motif dasar tersebut biasanya berasal dari jasmani manusia. Manusia adalah makhluk berjasmani sehingga perilakunya terpengaruh oleh insting atau kebutuhan jasmaninya. Motivasi sekunder adalah motivasi yang dipelajari. Motivasi dalam proses pembelajaran siswa tidak lain sebagai sumber energi psikologis (Muhamad Irham dan Novan Ardy Wiyani,2017: 56). Motivasi dalam belajar juga dapat diberikan melalui pembelajaran multikultural dimana guru 
mengenalkan siswa berbagai kebudayaan daerah lain sehingga siswa mengetahui adanya persamaan yang dimilikinya dengan teman-temannya sehingga timbul semangat untuk berkompetisi (Rustan, 2010).

Tujuan penulisan ini yang telah diuraikan sebelumnya, adapun tujuan tersebut adalah untuk mengetahui adanya penggunaan alat peraga sehingga siswa termotivasi untuk belajar, motivasi belajar siswa dapat ditingkatkan dengan penggunaan alat peraga (Rostina sundayana,2015:268) Motivasi belajar adalah keinginannya untuk melakukan kegiatan belajar untuk memenuhi kebutuhan dirinya baik yang dari dalam ataupun yang dari luar. Motivasi belajar juga merupakan faktor psikis yang bersifat non intelektual.

\section{METODE}

Metode adalah suatu cara yang dipergunakan untuk mencapai tujuan yang telah ditetapkan. Dalam proses interaksi belajar mengajar motode diperlukan seorang guru bervariasi sesuai dengan tujuan yang telah dicapai setelah pengajaran berakhir (Muhammad Yaumi,2013:71). Penelitian tindakan kelas merupakan suatu penelitian yang mengangkat masalahmasalah aktual yang dihadapi oleh guru di lapangan (Kunandar,2011:43) Penelitian tindakan kelas atau PTK (Classroom Action Research) memilikin peranan yang sangat penting dan strategis untuk meningkatkan mutu pembelajaran apabila diimplementasikan dengan baik dan benar.

Di implementasikan dengan baik maksudnya bahwa yang terlibat dalam PTK (Guru) mencoba dengan baik mengembangkan kemampuan dalam mendeteksi dan menyelesaikan masalah-masalah yang ada di dalam pembelajaran kelas melalui tindakan yang bermakana yang diperhitungkan dapat memecahkan masalah atau memperbaiki situasi dan secara teliti mengamati pelaksanaannya untuk mengetahui tingkat keberhasilannya. Subjek penelitian adalah siswa kelas III SD Islam DatokSulaiman Palopo, tahun pelajaran 2018/2019 semester ganjil yang berjumlah 28 orang ( 12 perempuan dan 12 laki-laki. Untuk mengumpulkan data dalam penelitian ini dilakukan dengan wawancara observasi, angket, dan dokumentasi. Rumus yang digunakan untuk mencari hasil dari mean data tunggal yang seluruh skornya berfrekuensi satu adalah sebagai berikut $\mathrm{P}=\frac{\mathrm{A}}{\mathrm{B}} \times 100 \%, \mathrm{P}=$ Presentase respon siswa, $\mathrm{A}=$ Proporsi siswa yang memilih, $\mathrm{B}=$ Jumlah siswa (responden) (Trianto,2008:173). 
6 | Alni

\section{HASIL PENELITIAN}

Hasil penelitian menunjukkan bahwa dengan penggunaan alat peraga dalam pembelajaran matematika siswa menjadi termotivasi, penggunaan alat peraga dalam pembelajaran matematika motivasi siswa menjadi meningkat hal tersebut dapat dilihat pada data yang diperoleh menunjukkan bahwa nilai rata-rata di kelas III pada siklus I mencapai 80,53, namun dalam pembelajaran ini masih ada beberapa siswa yang belum maksimal dan peneliti melakukan perbaikan dan dilanjutkan ke siklus II. Maka motivasi siswa ditingkatkan dengan hasil nilai rata-rata mencapai 89,82. Berdasarkan kriteria ketuntasan Minimal (KKM) pada mata pelajaran matematika sudah mencapai hasil dan peneliti mengakhiri penelitian ini sampai siklus II.

A. Gambaran proses pembelajaran Matematika kelas III SD Islam Datok Sulaiman Palopo melalui penggunaan alat peraga Perencanaan, pada tahap ini hal-hal yang dilakukan adalah:

Perencanaan ini yaitu sebagai berikut: Menentukan materi yang akan diajarkan, Membuat Rencana Pelaksanaan Pembelajaran (RPP), Membuat lembar observasi aktivitas siswa untuk melihat peningkatan hasil belajar siswa, membuat lembar observasi aktivitas guru untuk melihat perubahan belajar siswa, Menyusun tes evaluasi tentang materi yang telah diajarkan.

Pelaksanaan Tindakan, tahap ini, kegiatan pembelajaran dilaksanakan sesuai dengan rencana pelaksanaan pembelajaran yang telah dipersiapkan sebelumnya. Kegiatan pembelajaran diawali dengan membaca do'a sebelum memulai kegiatan proses belajar mengajar, Guru melakukan langkah pembelajaran sesuai dengan skenario pembelajaran (rencana pembelajaran terlampir),Siswa mengikuti kegiatan pembelajaran dan melaksanakan kegiatan sesuai dengan skenario kegiatan belajar mengajar, Pengamat melakukan pengamatan sesuai dengan instrument pengamatan tentang aspek proses pembelajaran yang dilakukan guru dan aktivitas siswa dalam kegiatan pembelajaran.

Observasi, pada tahap ini untuk mengetahui proses pembelajaran yang dilakukan dan aktivitas siswa dalam kegiatan pembelajaran dengan menggunakan lembar observasi peneliti dan yang menjadi sasaran observasi 
peneliti yaitu aspek kognitif. Data hasil penelitian kognitif (pengamatan) dilakukan untuk siswa, dan indikator aspek proses pembelajaran yang dilakukan guru dalam kegiatan pembelajaran sesuai dengan instrumen pengamatan. Apsek-aspek proses pembelajaran yang dilakukan guru meliputi perencanaan, kegiatan utama, dan pemantapan, Refleksi : Tahap selanjutnya adalah mengadakan refleksi yaitu membahas dan mengevaluasi kegiatan pembelajaran yang baru saja dilaksanakan.

Refleksi dilakukan untuk mengetahui kekurangan atau kendala siklus I. Pelaksanaan pada siklus I dapat dikatakan cukup baik, namun masih ada beberapa kendala. Kendala yang dimaksud adalah: Siswa masih kurang aktif dalam menyampaikan pendapat dan kurang menjawab pertanyaan, siswa masih kurang memperhatikan pelajaran pada saat guru sedang menjelaskan. Melihat kendala-kendala tersebut maka perlu dilakukan tindakan perbaikan agar hasil pembelajaran pada siklus II bisa lebih optimal. Kegiatan pembelajaran yang akan dilaksanakan pada siklus II penampilan mengajar guru akan ditingkatkan secara lebih baik dengan mengacu kepada kelemahankelemahan yang terjadi pada siklus I.

B. Peningkatan motivasi belajar dengan penggunaan alat peraga pada materi Mengenal mata uang Rupiah

Deskripsi Prasiklus telah dikemukakan pada BAB pendahuluan bahwa motivasi belajar siswa tergolong rendah dikarenakan guru dalam kegiatan pembelajaran lebih banyak menggunakan metode ceramah, dan pemberian tugas sehingga siswa kurang bergairah dan merasa jenuh dalam proses pembelajaran. Proses pembelajaran matematika dilaksanakan dengan urutan sebagi berikut: pertama guru menjelaskan sedikit materi, kedua siswa disuruh membaca buku teks dan merangkum sementara guru sibuk melaksanakan kegiatan lain, yang antara lain mengerjakan administrasi, ketiga siswa disuruh mengerjakan soal-soal yang ada dalam kumpulan LKS, dan selanjutnya hasil pekerjaan dikumpulkan untuk dinilai. 


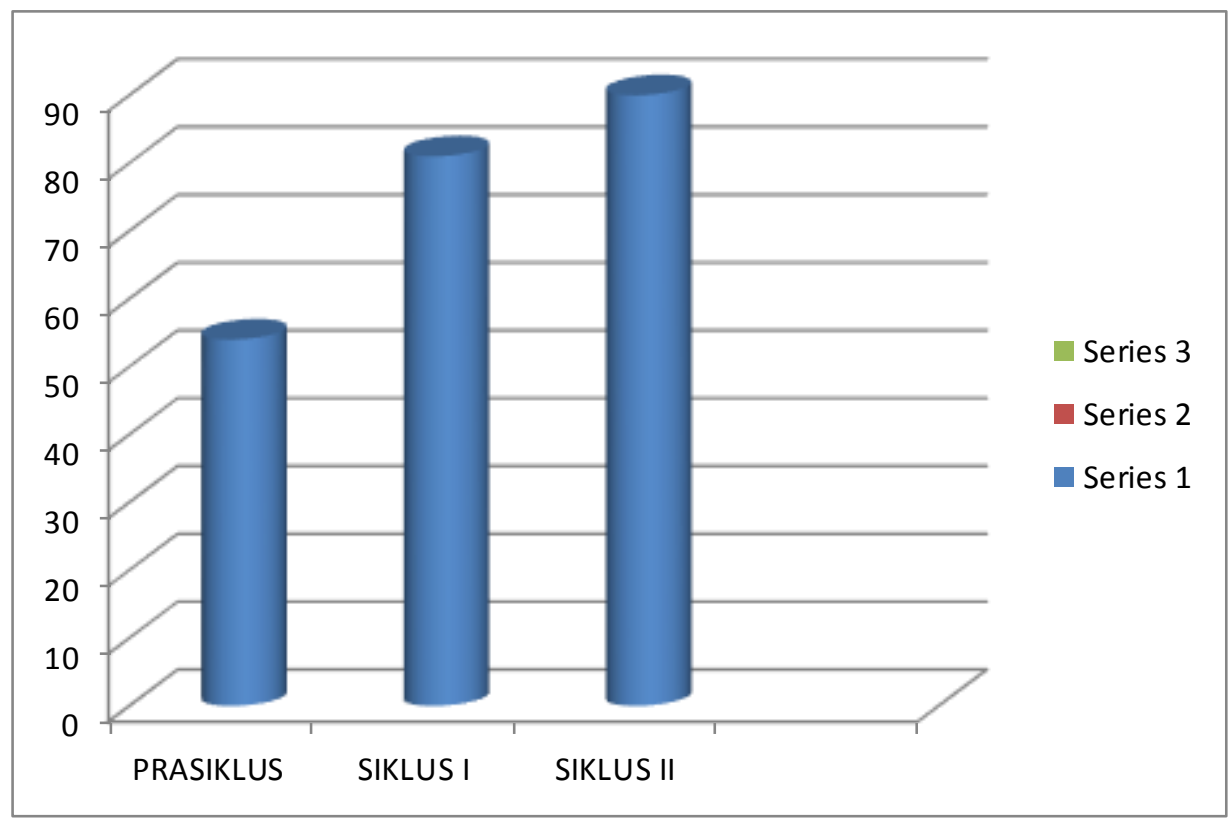

Gambar 1. Digram Penggunaan alat peraga

Berdasarkan pada gambar diagram diatas menunjukkan bahwa dengan penggunaan alat peraga dapat meningkatkan motivasi belajar siswa . Diketahui dari 28 siswa yang mengikuti tes pada prasiklus ternyata ada 0 siswa yang mendapat nilai termasuk kategori sangat baik, 5 siswa yang mendapat nilai termasuk kategori baik, 8 siswa yang mendapa nilai termasuk kategori cukup, 6 siswa mendapat nilai termasuk kategori kurang dan 9 siswa mendapat nilai termasuk kategori sangat kurang.

Deskripsi Siklus I dilakasanakan selama 3 kali pertemuan, dengan 2 kali tatap muka dan 1 kali evaluasi dipertemuan akhir siklus. Hasil evaluasi siklus I sehinnga nilai rata-rata hasil belajar siswa kelas III SD Islam Datok Sulaiman diperoleh dengan rumus rata-rata: $\frac{2.225}{28}=80,53$, jadi nilai rata-rata siswa dengan menggunakan alat peraga dalam pembelajaran mateamtika diatas menunjukkan bahwa dari 28 siswa yang mengikuti tes evaluasi pada siklus I siswa yang mendapat nilai $\geq 80,53$ sebanyak 20 orang dan yang mendapat nilai dibawah KKM sebanyak 8 orang dalam pembelajaran pada siklkus ini masih ada beberapa siswa yang masih tergolong kurang kemudian peneliti melanjutkan ke siklus II.

Deskripsi Siklus II dilakukan 3 kali pertemuan, dengan 2 kali tatap muka dan 1 kali evaluasi dipertemuan akhir siklus. Hasil evaluasi siklus II nilai 
rata-rata siswa SD Islam DatokSulaiman Palopo diperoleh dengan rumus rata rata $\frac{2.515}{28}=89,82$, jadi nilai rata-rata siswa dengan penggunaan alat peraga dalam pembelajaran Matematika pokok di atas menunjukkan bahwa dari 28 siswa yang mengikuti tes evaluasi pada siklus II siswa yang mendapat nilai $\geq$ 70 sebanyak 28 orang dan tidak ada yang mendapat di bawah nilai KKM. Motivasi belajar siswa setelah penggunaan alat peraga pada siklus II tidak ada siswa yang termasuk kategori gagal, tidak ada siswa yang termasuk kategori kurang, tidak ada siswa termasuk kategori cukup, tidak ada siswa yang termasuk kategori baik, dan siswa yang termasuk kategori sangat baik sebanyak 28 orang.

\section{PEMBAHASAN}

Berdasarkan pembahasan ini dapat diuraikan hasil penelitian mengenai peningkatan motivasi belajar matematika melalui penggunaa alat peraga. Berdasarkan penelitian, bagaimana penggunaan alat peraga dalam pembelajaran matematika siswa menjadi termotivasi untuk belajar kelas III SD Islam Datok Sulaiman Palopo, kemudian penggunaa alat peraga dapat meningkatkan motivasi belajar siswa, hal ini dikarenakan bahwa pembelajaran dengan penggunaan alat peraga dalam proses pembelajaran dapat menarik perhatian siswa sehingga membantu siswa meningkatkan motivasi dan memudahkan pemahaman siswa terhadap materi yang telah disampaikan guru.

Alat peraga atau lebih dikenal dengan media merupakan jamak dari kata medium adalah suatu saluran untuk komunikasi. Media berarti penghubung pengantar pesan dari pengirim ke penerima pesan. Alat peraga juga ini dapat digunakan untuk memperagakan fakta konsep prinsip atau prosedur tertentu agar tampak lebih nyata (konkret) (Ibrahim, 20013:12). Pemanfaatan alat peraga yaitu semua alat bantu pendidikan dalam pengajaran, yang berupa benda ataupun perbuatan yang paling konkrit sampai ke yang paling abstrak, yang dapat memudahkan pemahaman siswa. Alat peraga matematika merupakan benda konkrit yang dirancang, dibuat, dihimpun secara sengaja digunakan untuk membantu mengembangkan prinsip-prinsip dalam matematika. Dengan alat peraga yang abstrak itu dapat 
$10 \mid$ Alni

disajikan dalam bentuk model-model berupa benda konkrit yang dapat dilihat dipegang diputar balikan sehingga mudah di pahami. Alat peraga ini digunakan dalam media pembelajaran yang mrupakan bentuk alat komunikasi yang dapat digunakan untuk menyampaikan informasi dari sumber ke siswa secara terencana sehingga tercipta lingkungan belajar yang kondusif dimana penerimanya dapat melakukan proses belajar secara efisien dan efektif Hal ini sesuai dengan pendapat (Hamzah \& Nina Lamatenggo, 2011 : 122). Media pembelajaran merupakan alat komunikasi dalam bentuk cetak maupun pandang dan dengan termasuk perangkat keras Menurut ( Rusman, 2013 :170).

Hasil belajar siswa digunakan untuk mengetahui sejauh mana perkembangan pemahaman siswa terhadap materi pembelajaran yang dinyatakan dalam bentuk nilai. Menyatakan bahwa motivasi belajar siswa dapat dilihat dari tingkat keberhasilan siswa dalam mempelajari materi pelajaran di sekolah yang dinyatakan dalam skor yang diperoleh dari hasil tes mengenal sejumlah materi pelajaran tertentu (Ahmad Susanto 2014:5 ). Motivasi belajar ini digunakan untuk melihat perubahan tingkahlaku yang relatif permanen dalam diri seseorang sebagai akibat dari interaksi seseorang dengan lingkungannya. Hasil belajar memiliki beberapa ranah atau kategori dan secara umum merujuk kepada aspek pengetahuan, sikap, dan keterampilan (Hamzah B Uno, 2012: 213).

Berdasarkan presentase ketuntasan hasil belajar siswa kelas III SD Islam Datok Sulaiman Palopo setelah menggunakan media pembelajaran yaitu alat peraga pada pembelajaran matematika, dapat dilihat bahwa banyaknya siswa yang tuntas pada siklus I sebanyak 20 siswa atau 72\% dan banyaknya siswa yang tidak tuntas sebanyak 8 siswa , sedangkan siswa yang tuntas pada siklus II sebanyak 28 siswa sekitar 100\%. Berdasarkan hasil tes siklus II menyatakan bahwa dari 28 siswa yang mengikuti tes hasil evaluasi, yang tuntas 28 siswa. Dengan demikian terjadi peningkatan yaitu dari $72 \%$ menjadi $100 \%$. Nilai rata-rata hasil belajar peningkatan pengetahuan siswa terhadap materi pembelajaran. 
Meningkatnya motivasi siswa juga di dukung dengan adanya peningkatan hasil belajar siswa pada setiap siklus. Hal ini ditunjukkan dari adanya peningkatan perolehan nilai tes siklus I dan siklus II. Pada siklus I ratarata kelas perolehan nilai prasiklus 53,39 pada siklus I rata-rata nilai tes yang diperoleh siswa meningkat menjadi 81,60 sedangkan siklus II nilai tes yang diperoleh 89,82.. Peningkatan motivasi siswa dalam belajar disertai dengan peningkatan hasil belajar.

\section{PENUTUP}

Pada bagian ini menyajikan ringkasan dari uraian mengenai hasil dan pembahasan, mengacu pada tujuan penelitian. Berdasarkan kedua hal tersebut dikembangkan pokok-pokok pikiran baru yang merupakan esensi dari temuan penelitian.

Berdasarkan hasil penelitian dan pembahasan maka dapat disimpulkan bahwa: Penggunaan alat peraga dapat meningkatkan motivasi belajar siswa kelas III SD Islam Datok Sulaiaman Palopo pada mata pelajaran Matematika. Hal ini dapat terlihat dari perolehan skor rata-rata hasil belajar siswa pada siklus I yaitu 81,53 sedangkan perolehan skor hasil belajar siswa pada siklus II yaitu 89,82 dapat dikategorikan motivasi belajar siswa meningkat. Media pembelajaran sangat membantu dalam peningkatan hasil belajar siswa. Penggunaan alat peraga merupakan salah satu media pendidikan guna membantu proses belajar mengajar agar proses komunikasi dapat berhasil dengan baik secara efektif dan efisien.

\section{DAFTAR PUSTAKA}

Ahmadi H.Abu Ahmadi Joko Tri Prasetya. 2001. Strategi Belajar Mengajar, Bandung: Pustaka Setia.

Arsyad Azhar. 2013. Media Pembelajaran, Jakarta :Raja Grafindo Persada.

Aunurrahman. 2014. Belajar dan Pembelajaran, Bandung: Alfabeta.

B. Uno Hamzah. 2012. Teori Motivasi dan Pengukurannya, Jakarta: Pt Bumi Aksara.

Dimyati, Mudjiono. 2009. Belajar dan Pembelajaran, PT.Asdi Mahasatya: Rinneka Cipta.

Haling Abdul. 2007. Belajar dan Pembelajaran, Jakarta: PT Rineka Cipta. 
$12 \mid$ Alni

Irham, Muhamad dan Novan Ardy Wiyani. 2017. Psikologi Pendidikan Teori dan Aplikasi dalam Proses Pembelajaran. Jogjakarta: Ar-Ruzz Media.

Ibrahim. 2003. Perencanaan Pengajaran, Jakarta: PT Rineka Cipta.

J.Tombokan Runtukahu. 2014. Pembelajaran Matematika Dasar Bagi Anak Berkesulitan Belajar, Yogyakarta: Ar-ruzz media.

Kunandar. 2011. Langkah mudah Penelitian Tindakan Kelas, Jakarta: PT Raja Grafindo Persada.

Rusman. 2013. Pembelajaran Berbasis Teknologi Informasi dan Komunikasi, Jakarta : Raja Grafindo Persada.

Rustan, E. (2001). Budaya Leluhur dalam Memperkukuh Tatanan Masyarakat di Era Globalisasi. In Seminar Internasional Pemertahanan Identitas Masyarakat Multikultural di Era Globalisasi (pp. 79-86). Surabaya.

Rustan, E. (2010). Pembelajaran Bahasa dan Sastra Daerah Berbasis Multikultural dalam Mewujudkan Pendidikan yang Berkarakter di Era Globalisasi. In Kongres International Bahasa-Bahasa Daerah Sulawesi Tenggara (pp. 247-249). Baubau.

Sukmadinata. Nana Syaodih. 2009. Landasan Psikologi Proses Pendidikan, Bandung: Remaja Rosdakarya.

Slameto. 2013. Belajar dan Faktor-faktor yang Mempengaruhinya, Jakarta: Rineka Cipta.

Sardiman. 2011. Interaksi dan Motivasi Belajar Mengajar, Jakarta: PT. Raja Grafindo Persada.

Sani Abdullah Ridwan. 2013. Inovasi Pembelajaran, Jakarta: Bumi Aksara.

Sanjaya Wina. 2009. Penelitian Tindakan Kelas, Jakarta : Kencana

Susanto Ahmad. 2014. Pengembangan Pembelajaran IPS, Jakarta: Prenada Media Group .

Sundayana Rostina. 2015. Media dan Alat Peraga dalam Pembelajran Matematika, Bandung: Alfabeta.

Syafri Santri Fatrima. 2016. Pembelajaran Matematika, Yogyakarta: Ruko Jambusari.

Syamsu S. 2017. Strategi Pembelajaran, Makassar: Media Pustaka

Trianto. 2008. Mendesain Pembelajaran Kontekstual di Kelas, Jakarta: Kencana.

Undang-undang dan Peraturan Pemerintah RI tentang Pendidikan. 2006. Departemen Agama RI 
Wena Made. 2013. Strategi Pembelajaran Inovatif Kontemporer, Jakarta: Bumi Aksara.

Yaumi Muhammad. 2013. prisip-prinsip desain pembeajaran, Jakarta: Kencana

-----Sengaja dikosongkan----- 